\title{
How do Pacific Island countries add up on contraception, abortion and reproductive coercion? Guidance from the Guttmacher report on investing in sexual and reproductive health
}

\author{
Angela Dawson ${ }^{1 *}\left(\mathbb{D}\right.$, Alec Ekeroma ${ }^{2}$, Donald Wilson ${ }^{3}$, Amanda Noovao-Hill $^{4,5}$, Leeanne Panisi ${ }^{6}$, Brooke Takala $^{7}$, \\ Kirsten Black ${ }^{8}$ and Deborah Bateson ${ }^{9}$
}

\begin{abstract}
The Guttmacher-Lancet Commission report on Sexual and Reproductive Health and Rights called for the acceleration of progress to achieve SRHR that is essential for sustainable development. To integrate the essential services defined in this report into universal health coverage in the 11 sovereign nations in the Pacific, quality data is required to ensure needs are met efficiently and equitably. However, there are no comprehensive reports for Pacific Island countries that provide insight into all areas of SRHR. We collated the latest literature to identify the most up-to-date relevant data from United Nations and Guttmacher Institute reports to discern gaps in SRHR information and services relating to contraception, abortion and reproductive coercion. Investment is urgently required to strengthen health information systems for SRHR in the Pacific.
\end{abstract}

Keywords: Reproductive health, Pacific Islands, Health information

\section{Background}

In 2018, the Guttmacher-Lancet Commission on Sexual and Reproductive Health and Rights (SRHR) outlined an essential package of sexual and reproductive health (SRH) interventions underpinned by human rights [1]. Globally, many of these SRHR goals remain neglected in policy and planning [2]. In the Pacific, addressing these key yet sensitive SRHR areas of contraception, abortion care, and reproductive coercion is crucial to achieving progress towards the Sustainable Development Goals (SDGs). However, advancement continues to be hampered by stigma and discrimination, opposition from religious institutions, insufficient knowledge, and misinformation

*Correspondence: angela.dawson@uts.edu.au

${ }^{1}$ The Australian Centre for Public and Population Health Research, Faculty of Health, University of Technology Sydney, Ultimo, Australia

Full list of author information is available at the end of the article
[3-5]. Additionally, the COVID-19 pandemic has likely exacerbated the challenges of achieving progress towards the SDGs, including the provision of universal access to SRH services and rights to ensure healthy lives and wellbeing (Target 3.7, SDG 3) and gender equality (Target 5.6, SDG 5). Modelling of the potential impact of the COVID19 pandemic on SRH in low and lower-middle-income countries, where services are disrupted [6], suggests that a 10\% decline in the use of short and long-acting reversible contraceptives would result in an additional 28,000 maternal deaths. Alongside worldwide extreme weather events and protracted human conflict, this pandemic has shone a spotlight on SRHR inequalities and sustainable development to address these inequalities.

Increased investment in SRH by governments to overcome disparities and meet the SDGs, as outlined by the recent Guttmacher report [2], requires evidence of country-specific gaps and challenges. This not only original author(s) and the source, provide a link to the Creative Commons licence, and indicate if changes were made. The images or other third party material in this article are included in the article's Creative Commons licence, unless indicated otherwise in a credit line to the material. If material is not included in the article's Creative Commons licence and your intended use is not permitted by statutory regulation or exceeds the permitted use, you will need to obtain permission directly from the copyright holder. To view a copy of this licence, visit http://creativecommons.org/licenses/by/4.0/. The Creative Commons Public Domain Dedication waiver (http://creativeco mmons.org/publicdomain/zero/1.0/) applies to the data made available in this article, unless otherwise stated in a credit line to the data. 
includes detailed data about contraception prevalence, fertility, and gender indicators but also information concerning the social-economic, legal, and political determinants of SRHR, which underlie inequity.

However, there are no comprehensive reports for Pacific Island countries that provide insight into all areas of SRHR. Available documents include data on a selection of countries [7, 8] or indicators [9]. Some reports combine data on specific groups of Pacific Island countries [10] or pool data from all countries to give a regional picture of Oceania [11]. These documents do not reveal the unique and diverse contexts of each Pacific Island country. Reports mainly focus on maternal health [12] or specific populations such as adolescents [13]. Demographic and Health surveys are only available for Samoa [14] and Multiple Indicator Cluster Surveys (MICS) for Vanuatu [15], Tonga [16] and Kiribati [17], and Samoa (preliminary findings, no dataset 2020). There is little understanding of the prevalence and outcomes of unsafe abortion. It is unclear what information is available concerning reproductive coercion that describes behaviours that interfere with a woman's autonomous reproductive health decision-making (e.g., sabotage of contraception and pregnancy coercion or controlling pregnancy outcomes) [18].

We sought to collate available information across multiple datasets to provide an up-to-date snapshot of SRHR in Pacific Island countries. We included where possible the prevalence of and access to contraception and abortion care and reports of gender-based violence and reproductive coercion for populations groups including women, adolescents, people with disabilities and lesbian, gay, bisexual, transgender and intersex (LGBTQI) people. We provide recommendations for enhancing data collection and reporting to support Pacific Island countries to meet their SRHR SDG targets.

\section{The island countries of the Pacific}

There are 11 countries according to the World Bank's Pacific Island grouping [19] with a collective population of about 2.3 million people (excluding Papua New Guinea $8.6 \mathrm{~m})$. These countries lie across the Oceanic cultural regions of Polynesia, Melanesia, and Micronesia (Fig. 1).

While the population of each of these 11 countries is under two-hundred thousand people and are youthful, they are culturally diverse, and most are in the

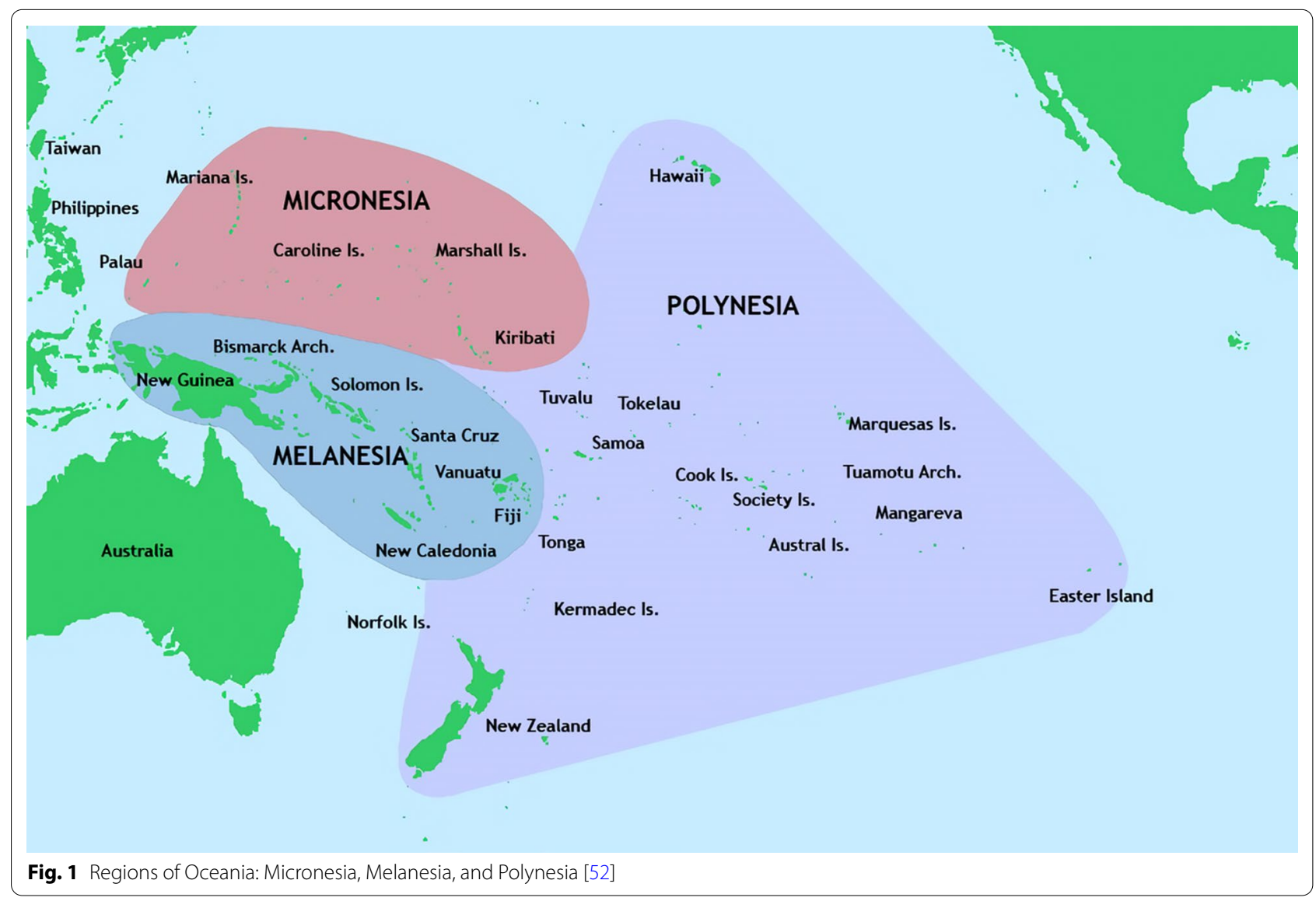


upper-middle-income country (UMIC), followed by the low and lower middle-income country (LLMIC) bracket [20]. Nauru is the most densely populated of the group, while the Solomon Islands and Vanuatu, which are among the poorest, are the least populated. Palau is the only high-income country (HIC) in this grouping and has the lowest population growth rate (Table 1).

\section{Reproductive health indicators, policy, and services \\ Contraception}

Research on contraception use, particularly by type, and the quality of contraceptive services is very limited in the Pacific. The SDG target 3.7 aims to ensure universal access to SRH care services, including family planning, SRH information and education, and integrating reproductive health into national strategies and programmes by 2030. Two key indicators are the: proportion of women of reproductive age (aged 15-49 years) who have their need for family planning satisfied with modern methods (Indicator 3.7.1); and the adolescent fertility rate (aged $10-14$ years; $15-19$ years) per 1000 women (Indicator 3.7.2). A review of intrauterine contraception across the Pacific identified that usage rates are very low across all Pacific Island countries with an overall prevalence rate of $0.3 \%$, ranging from $0.2 \%$ in Samoa to $3.8 \%$ in Nauru [21].

As per Table 2, up-to-date projections for these key indicators are available for unmarried and married women in six countries. For the remaining states, 2015 estimates are only available for in-union women. Estimated contraceptive prevalence rates are under $50 \%$ for all countries. Alongside low contraceptive prevalence rates, very high adolescent fertility rates of around 50 births per 1000 women aged 15-19 (compared with 12 per 1,000 in Australia) are documented in seven countries: Kiribati, Marshall Islands, Nauru, Samoa Solomon Island, Vanuatu, and Fiji. These rates suggest there is a large unmet need, particularly in younger women.

\begin{abstract}
Abortion
Abortion is legally restricted throughout the Pacific region but is permitted in certain circumstances in most countries, including, for example, if the pregnancy endangers a woman's life [22, 23] (see Table 2). No national data are collected on abortion in any Pacific Island country. One estimate of prevalence suggests that between $0 \%$ and $4 \%$ of $20-24$-year-olds have had an induced abortion, but this is likely to be underestimated [13]. However, in the Federated States of Micronesia, $12.8 \%$ of ever-pregnant women reported having an abortion [24]. Data from National Studies on Family Health and Safety (FHS) in some Pacific countries provide insight into induced abortion. The restricted nature of abortion likely affects women's ability to freely report whether they have undergone this procedure. None of the 634 women surveyed in the National Study on Domestic Violence against Women in Tonga reported having had an abortion [25].

Few details are available concerning abortion-related services across the Pacific. In Kiribati, none of the 15 health facilities visited as part of a UNFPA needs assessment provided information about services to prevent unsafe abortion and management of post-abortion care. Records of visits for care following unsafe abortion were not available [26].
\end{abstract}

Table 1 Estimated population size, growth, age group and density, country size, and income

\begin{tabular}{|c|c|c|c|c|c|c|c|}
\hline Country (last census/official estimates) & $\begin{array}{l}2020 \\
\text { population } \\
\text { estimate }\end{array}$ & Growth rate & $\begin{array}{l}\% \text { of } \\
\text { population } \\
15-24 \text { years }\end{array}$ & $0-24$ years & 2018 Density & Area $\left(\mathrm{km}^{2}\right)$ & Income group \\
\hline FSM (2010/2015) & 115,173 & $1.06 \%$ & 20.1 & 51.3 & $164 / \mathrm{km}^{2}$ & 700 & LLMIC \\
\hline Fiji (2017) & 897,295 & $0.73 \%$ & 16.4 & 45.4 & $49 / \mathrm{km}^{2}$ & 18,270 & UMIC \\
\hline Kiribati (2015) & 119,699 & $1.57 \%$ & 17.7 & 53.6 & $147 / \mathrm{km}$ & 810 & LLMIC \\
\hline Marshall Islands (2011/2017) & 59,190 & $0.68 \%$ & $18^{\mathrm{a}}$ & $58^{\mathrm{a}}$ & $329 / \mathrm{km}^{2}$ & 180 & UMIC \\
\hline Nauru $(2011 / 2015)$ & 10,824 & $0.63 \%$ & $17^{a}$ & $56^{\mathrm{a}}$ & $541 / \mathrm{km}^{2}$ & 20 & UMIC \\
\hline Palau (2015/2017) & 18,094 & $0.48 \%$ & $15^{\mathrm{a}}$ & $35^{\mathrm{a}}$ & $39 / \mathrm{km}^{2}$ & 460 & HIC \\
\hline Samoa (2016/2017) & 198,614 & $0.67 \%$ & 18.1 & 55.3 & $70 / \mathrm{km}^{2}$ & 2,830 & UMIC \\
\hline Solomon Islands (2009/2017) & 721,000 & $2.55 \%$ & 19.1 & 59.1 & $25 / \mathrm{km}^{2}$ & 27,990 & LLMIC \\
\hline Tonga (2016) & 105,845 & $1.15 \%$ & 20 & 54.7 & $147 / \mathrm{km}^{2}$ & 720 & UMIC \\
\hline Tuvalu (2012/2016) & 11,792 & $1.25 \%$ & $19^{\mathrm{a}}$ & $52^{\mathrm{a}}$ & $393 / \mathrm{km}^{2}$ & 30 & UMIC \\
\hline Vanuatu (2016) & 308,145 & $2.42 \%$ & 18.1 & 56.6 & $25 / \mathrm{km}^{2}$ & 12,190 & LLMIC \\
\hline
\end{tabular}

$\left.{ }^{[46]}\right]^{\mathbf{a}}[47] .{ }^{\mathbf{b}}[20]$ 


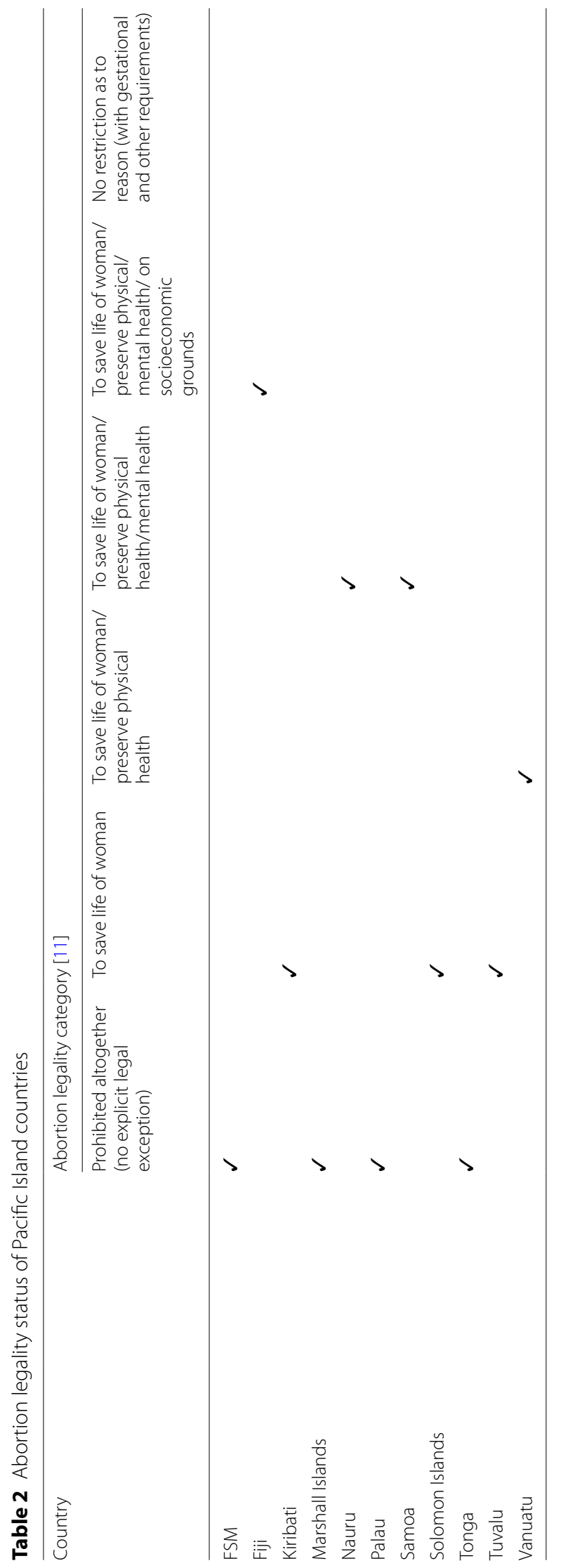




\section{Reproductive coercion}

The percentage of women subjected to physical and sexual intimate partner violence (IPV) in the last 12 months and their lifetime is shown in Table 3. IPV is used as a proxy measure [27] for the SDG 5.2.1 indicator: Proportion of ever-partnered women and girls aged 15 years and older subjected to physical, sexual or psychological violence by a current or former intimate partner in the previous 12 months, by a form of violence and by age.

Family Health and Safety (FHS) Studies undertaken in seven Pacific countries may shed some light on socio-cultural norms that affect a women's ability to make autonomous decisions. Indicators include being obliged to have sex with one's husband [24]. However, these surveys are outdated and do not include all operational definitions of violence, including those related to reproductive coercion. Exceptions are surveys from Kiribati and the Solomon Islands. These surveys indicate that $11.6 \%$ of currently partnered women in each country who had experienced physical or sexual partner violence reported that their partner had ever tried to stop family planning versus $9.3 \%$ and $7.2 \%$ respectively of those who had not experienced IPV [28]. The FHS survey from the Marshall Islands reports that $1.2 \%$ of women who experienced violence in pregnancy had abortions [29]. While in Palau, $0.8 \%$ of ever-pregnant respondents said that they have ever had an abortion and 1.7\% of ever abused women reported ever having an abortion compared to $0.5 \%$ of never abused women [30].
Research in other Pacific countries provides some understanding of reproductive coercion, but these are limited by sample size and date. In a study of respondents in Fiji who have experienced physical and/or sexual partner violence, $10.2 \%$ reported that their partner had ever refused or stopped contraception, and $13.6 \%$ stated that their current or most recent partner refused to use a condom [31]. In Vanuatu, a needs assessment identified that $14-21 \%$ of women wishing to use family planning methods and $74-78 \%$ of women wanting to use condoms have either been subjected to or fearful of physical and sexual violence from their intimate partner [32].

\section{Discussion}

This review of available data has identified gaps in SRH information and services in many Pacific Island countries. This leaves many women and other marginalised populations such as LGBTI people vulnerable to breaches of their SRHR. The Pacific Islands Forum, the region's premier political and economic policy organisation, has recognised that significant barriers to equitable SRHR still exist and that comprehensive SDG planning, implementation and reporting cannot be achieved without access to accurate data [33, 34].

Of particular note is the widespread lack of data on contraception, abortion, and reproductive coercion amongst adolescent sexually active unmarried women and those with a disability [35]. This is due to the ethical and socio-cultural precariousness of data sampling

Table 3 Selected reproductive indicators across 11 Pacific Countries

\begin{tabular}{|c|c|c|c|c|c|c|}
\hline Country & $\begin{array}{l}\text { Contraception demand } \\
\text { satisfied by modern } \\
\text { methods: married } \\
\text { women } 2020^{a}\end{array}$ & $\begin{array}{l}\text { Contraception demand } \\
\text { satisfied by modern } \\
\text { methods: unmarried } \\
\text { women } 2020^{a}\end{array}$ & $\begin{array}{l}\text { CPR } \\
\text { modern all } \\
\text { women }\end{array}$ & $\begin{array}{l}\text { AFR } \\
2015-2020 \\
15-19 \text { yrs }\end{array}$ & $\begin{array}{l}\text { \%of women subjected } \\
\text { to physical \&/or } \\
\text { sexual IPV in the last } \\
12 \text { months }^{h} \text { (year of } \\
\text { collection) }\end{array}$ & $\begin{array}{l}\text { \%of women subjected to } \\
\text { physical \&/or sexual IPV } \\
\text { in their lifetime } \text { (year of }^{\text {h yellection) }}\end{array}$ \\
\hline FSM & - & - & $49.5^{c}$ & $13.9^{c}$ & $26(2014)$ & 32.8 (2014) \\
\hline Fiji & $65.3^{\mathrm{a}}$ & $59.7^{a}$ & $30^{\mathrm{a}}$ & $49.4^{c}$ & $23.7(2010)$ & $64.1(2010)$ \\
\hline Kiribati & $44.7^{\mathrm{a}}$ & $72.7^{a}$ & $16.2 \mathrm{a}$ & $51^{d}$ & 43.4 (2018) & $61(2018)$ \\
\hline Marshall Islands & $57^{b}$ & - & $43.1^{b}$ & $85^{e}$ & $20(2014)$ & $50.9(2012)$ \\
\hline Nauru & $44.6^{b}$ & - & $27.5^{b}$ & $81^{e}$ & $22.1(2013)$ & $48.1(2013)$ \\
\hline Palau & $55.4^{b}$ & - & $34.4^{b}$ & $29^{e}$ & $9.9(2013)$ & $25.2(2013)$ \\
\hline Samoa & $37.8^{\mathrm{a}}$ & $40.8^{a}$ & $15.9 \mathrm{a}$ & $55^{f}$ & $22(2000)$ & $46.1(2000)$ \\
\hline Solomon Islands & $55.5^{\mathrm{a}}$ & $52.4^{\mathrm{a}}$ & $32^{\mathrm{a}}$ & $78^{c}$ & $41.8(2008)$ & $63.5(2008)$ \\
\hline Tonga & $50.7^{\mathrm{a}}$ & $60^{\mathrm{a}}$ & $17^{\mathrm{a}}$ & $30^{g}$ & 18.9 (2009) & 39.6 (2009) \\
\hline Tuvalu & $43.7^{b}$ & - & $27.1^{b}$ & $44^{e}$ & $25(2007)$ & 36.8 (2007) \\
\hline Vanuatu & $59.7^{a}$ & $63.1^{\mathrm{a}}$ & $40.3^{a}$ & $49.4^{c}$ & 44 (2009) & $60(2009)$ \\
\hline
\end{tabular}

${ }^{1}$ Demand satisfied by modern = Women of reproductive age (aged 15-49 years) who have their need for family planning satisfied with modern methods Median = MEDIAN ESTIMATE (adjusted) projected. CPmod = Women of reproductive age (15-49 years) who are currently using any modern method of contraception

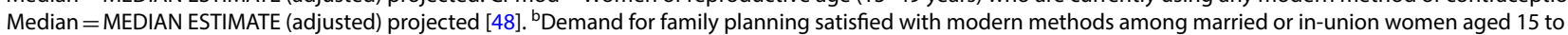
49, 2015 Median estimate. Contraceptive prevalence (modern methods) among married or in-union women aged 15 to 49,2015 Median estimate [49]. ' Age-specific fertility rates (births per 1,000 women) 15-19 years 2015-2020 [46]. ${ }^{\mathrm{d}}$ [17]. ${ }^{\mathrm{e}}$ Age-specific fertility rates (births per 1000 women) 15-19 years [50]. ${ }^{\mathrm{f}}[14] .{ }^{9}$ [16]. ${ }^{\mathrm{h}}$ [51] 
among these groups [34]. Data collection on contraceptive indicators is essential for planning and evaluating services and determining workforce needs, and without it, a coordinated response is unattainable. The lack of abortion data is also problematic as this impedes knowledge of pregnancy outcomes and prevents an understanding of health needs. Research indicates an association between higher maternal mortality rates and unsafe abortion and restrictive abortion laws [36]. Unsafe abortion contributes to 30 maternal deaths per 100,000 live births in Oceania, higher than the 20 per 100,000 live births reported for South-eastern Asia [37]. The decriminalisation of abortion increases the proportion of safe abortions [38].

SRH data collection is also impeded by a lack of recognition of sexual diversity in many Pacific Island countries [39] and an inability to record whether a person identifies as LGBTI within existing data sets. Gaps in reproductive coercion data are also concerning as this disproportionately affects women and LGBTQI people who are also experiencing IPV and women of lower socioeconomic status $[18,40]$. Besides, no data are available that document the experience of LGBTQI people and their satisfaction with SRH services. This data gap prevents an examination of health inequities that are directly linked to societal discrimination of sexual orientation, variations in sex characteristics and gender identity, as well as structural barriers that restrict access to appropriate health care.

Beyond data collection, one of the key challenges in meeting any of the SDG goals is community understanding about SRH. Several studies have highlighted the paucity of knowledge of contraception amongst women in studies in the Pacific. A cross-sectional study of 1441 women in the Solomon Islands reported that one in six pregnant women (16.95) did not know any modern contraceptive methods [41]. Another survey of 3,092 women who had given birth at the Colonial War Memorial Hospital in Fiji found that 59\% (119/202) had not previously used any contraception method [42].

Statistical modelling of data from Vanuatu and the Solomon Islands has found that increasing investment in family planning would increase modern contraception from 36.8 to $65.5 \%$ in Vanuatu and 28.5 to $37.6 \%$ in the Solomon Islands by 2025 . These investments have also been predicted to reduce unintended pregnancy, fertility rates, and improve maternal and infant outcomes while saving \$112 million in health and education expenditure [43].

Increasing knowledge about contraception is important, but so is changing attitudes towards gender-based violence. The recent MICS surveys include data on attitudes toward domestic violence, including whether a husband is justified in beating his wife if she refuses to have sex with him $[17,16]$. These surveys reveal alarmingly high rates of acceptance of violence towards women for various reasons, but data on reproductive coercion is not explicitly collected. As such, there is no information on whether partner/spousal opposition prevents women's efforts to use contraceptives or if partner/spousal abuse prevents successful use of contraceptives (e.g., contributes to contraceptive failure) [44].

\section{Conclusion}

Investment is urgently required to improve the health information systems in Pacific countries. Capacity building is needed to support data collection to plan SRH services that can adequately respond to all populations' needs and provide a benchmark to assess service and policy quality. National routine, complete and systematic data collection on contraception, abortion, and reproductive coercion should be implemented and reported annually in each country. This will require developing a minimum data set of standardised SRH information that recognises the integrated nature of $\mathrm{SRH}$ is required to develop comprehensive services. Indicators such as the SDG targets and those suggested by the WHO for reproductive health programs in the Western Pacific region [45] are a useful starting point; however, they must be developed in collaboration with vulnerable populations. This partnership approach will ensure the acceptability of the proposed minimum data set and raise awareness and understanding of the importance of SRH and the demand for services. Alongside these efforts, strengthening Pacific nations' health data collection systems is essential to assess the achievement of an integrated and comprehensive rights-based approach to SRH.

\section{Abbreviations \\ AFR: Adolescent fertility rate; CPR: Contraceptive prevalence rate; FHS: Family Health and Safety surveys; HIC: High-income country; IPV: Intimate partner violence; LGBTQI: Lesbian, gay, bisexual, transgender and intersex people; LLMIC: Low and lower-middle-income country; MICS: Multiple Indicator Cluster Surveys; SDGs: Sustainable Development Goals; SRHS: Sexual and reproductive health and rights; WHO: World Health Organization; UMIC: Upper-middle-income country; UN: United Nations.}

\section{Acknowledgements}

We would like to thank Isla Collee for her assistance with collating the literature and tabulating indicators.

\section{Authors' contributions}

$A D, D B$ and $K B$ conceived the study and $A D$ drafted the manuscript. Feedback was provided by $A E, D W, A N-H, L P$ and BK. All authors read and approved the final manuscript.

Funding

This study was unfunded.

Availability of data and materials

All data is available in the public domain. 


\section{Declarations}

Ethics approval and consent to participate

Not applicable.

\section{Consent for publication}

Not applicable.

\section{Competing interests}

The authors declare that they have no competing interests.

\section{Author details}

${ }^{1}$ The Australian Centre for Public and Population Health Research, Faculty of Health, University of Technology Sydney, Ultimo, Australia. ${ }^{2}$ National University of Samoa, Apia, Samoa. ${ }^{3}$ Institute of Pacific Health Research, College of Medicine, Nursing and Health Sciences, Fiji National University, Suva, Fiji. ${ }^{4}$ Lautoka Hospital, Lautoka, Fiji. ${ }^{5}$ College of Medicine, Nursing and Health Sciences, Fiji National University, Suva, Fiji. ${ }^{6}$ National Referral Hospital Solomon, Honiara, Solomon Islands. ${ }^{7}$ Marshall Islands Women's Research Initiative, Majuro, Marshall Islands. ${ }^{8}$ Discipline of Obstetrics, Gynaecology and Neonatology, The Sydney University Central Clinical School, Camperdown, Australia. ${ }^{9}$ The Australian Centre for Public and Population Health Research, University of Technology Sydney, Sydney, Australia.

Received: 17 December 2020 Accepted: 16 March 2021

Published online: 25 March 2021

\section{References}

1. Starrs AM, Ezeh AC, Barker G, Basu A, Bertrand JT, Blum R, Coll-Seck AM, Grover A, Laski L, Roa M, et al. Accelerate progress - sexual and reproductive health and rights for all: report of the Guttmacher-Lancet Commission. Lancet. 2018;391(10140):2642-92.

2. Sully E, Biddlecom A, Darroch J, Riley T, Ashford L, Lince-Deroche N, Firestein L, Murro R. Adding it up: investing in sexual and reproductive health 2019. New York: Guttmacher Institute; 2020. https://www.guttmacher. org/report/adding-it-upinvesting-in-sexual-reproductive-health-2019.

3. Davis J, Vyankandondera J, Luchters S, Simon D, Holmes W. Male involvement in reproductive, maternal and child health: a qualitative study of policymaker and practitioner perspectives in the Pacific. Reprod Health. 2016;13(1):81.

4. O'Connor M, Rawstorne P, Iniakwala D, Razee H. Fijian adolescent emotional well-being and sexual and reproductive health-seeking behaviours. Sex Res Social Policy. 2019;16(3):373-84.

5. Winn-Dix EA, Nathan SA, Rawstorne P. Informing the introduction of contraceptive implants in the Pacific: a mixed methods study of contraceptive beliefs and behaviours in Tonga. 2016;40(2):115-9.

6. Riley T, Sully E, Ahmed Z, Biddlecom A. Estimates of the potential impact of the COVID-19 pandemic on sexual and reproductive health in low-and middle-income countries. Int Perspect Sex Reprod Health. 2020;46:73-6.

7. Thanenthiran S. Access to Contraception and Family Planning in Asia and the Pacific Region. Asian-Pacific Resource \& Research Centre for Women 2019. https://arrow.org.my/publication/icpd25-access-to-contraceptionand-family-planning-in-asia-and-the-pacific-region/.

8. UN DESA. Contraceptive Use by Method 2019: Data Booklet New York: United Nations, Department of Economic and Social Affairs, Population Division; 2019. https://www.un.org/development/desa/pd/sites/www. un.org.development.desa.pd/files/files/documents/2020/Jan/un_2019_ contraceptiveusebymethod_databooklet.pdf.

9. IPPF. Niu Vaka. IPPF Pacific Strategy 2019-2022. London: International Planned Parenthood Federation; 2018. https://www.ippfeseaor.org/sites/ ippfeseaor/files/2019-11/IPPF\%20Pacific\%20Strategy\%20-\%20Web\%20\% 28New\%29.pdf.

10. Smith SA. Sexual and reproductive health of micronesians: a systematic review of the literature. Asia Pac J Public Health. 2012;25(1):7-18.

11. Singh S, Remez L, Sedgh G, Kwok L, Onda T. Abortion worldwide 2017: uneven Progress and unequal Access. New York: Guttmacher Institute; 2018. https://clacaidigital.info/bitstream/handle/123456789/1114/Abort ion\%20worldwide\%202017.pdf?sequence=5\&isAllowed=y.
12. UNFPA WHO UNICEF SPC. The State of The Pacific's Reproductive, Maternal, Newborn, Child and Adolescent Health Workforce. Fiji: UNFPA Pacific Sub-Regional Office; 2019. https://pacific.unfpa.org/en/publications/ state-pacifics-rmncah-workforce-2019-report.

13. UNFPA UNESCO WHO: Sexual and reproductive health of young people in Asia and the Pacific A Review of Issues, Policies and Programmes. Bankok: UNFPA; 2015. https://asiapacific.unfpa.org/en/publications/ sexual-and-reproductive-health-young-people-asia-and-pacific.

14. SBS. Fact Sheet -Samoa DHS - MICS 2019-20 Preliminary Results. Appia: Samoa Bureau of Statistics, UNICEF; 2020. https://mics-surveys-prod.s3. amazonaws.com/MICS6/East\%20Asia\%20and\%20the\%20Pacific/Samoa/ 2019-2020/Preliminary\%20report/Factsheet\%20Samoa\%20DHS-MICS\% 202019-20_English.pdf.

15. Government of Vanuatu. Vanuatu Multiple Indicator Cluster Survey 2007. Port Vila: Ministry of Health, Government of Vanuatu; 2008. https://www. rhsupplies.org/uploads/tx_rhscpublications/Vanuatu_2007_MICS_Engli sh_01.pdf.

16. TSD. Tonga Multiple Indicator Cluster Survey 2019, Survey Findings Report. In. Nuku'alofa, Tonga Tonga Statistics Department; 2020. https:// mics-surveys-prod.s3.amazonaws.com/MICS6/East\%20Asia\%20and\% 20the\%20Pacific/Tonga/2019/Survey\%20findings/Tonga\%202019\% 20MICS\%20Survey\%20Findings\%20Report_English.pdf.

17. KNSO. Kiribati Social Development Indicator Survey 2018-19 Survey Findings Report. Tarawa: Kiribati National Statistics Office, Ministry of Health, UNICEF; 2019. https://mics-surveys-prod.s3.amazonaws.com/MICS6/ East\%20Asia\%20and\%20the\%20Pacific/Kiribati/2018-2019/Survey\%20fin dings/Kiribati\%20MICS\%20SDIS\%202018-19\%20Survey\%20Findings\% 20Report_English.pdf.

18. Grace K, Anderson J. Reproductive coercion: a systematic review. Trauma Violence Abuse. 2018;19(4):371-90.

19. The World Bank In Pacific Islands https://www.worldbank.org/en/count ry/pacificislands/overview.

20. World Bank: World Bank Country and Lending Groups. New York: World Bank; 2020. https://datahelpdesk.worldbank.org/knowledgebase/artic les/906519-world-bank-country-and-lending-groups.

21. Bateson D, Kang S, Paterson H, Singh K. A review of intrauterine contraception in the Asia-Pacific region. Contraception. 2017;95(1):40-9.

22. CRR. The world's abortion laws 2018 http://worldabortionlaws.com/. In. New York: Center for Reproductive Rights; 2018.

23. Global Abortion Policies Database. https://abortion-policies.srhr.org/,

24. FSM DHSA. Federated States of Micronesia Family Health and Safety Study. FSM Department of Health and Social Affairs, Australian Government's Department of Foreign Affairs, United Nations Population Fund Pacific Sub-Regional Office; 2014. https://asiapacific.unfpa.org/sites/defau It/files/pub-pdf/FSM_family_health_safety_survey_report_2014.pdf.

25. Jansen H, Johansson-Fua S, Hafoka-Blake B,'Ilolahia G. National Study on Domestic Violence against Women in Tonga 2009. Nuku'alofa: Ma`a Fafine mo e Famili Inc; 2012. https://pacific.unfpa.org/sites/default/files/ pub-pdf/tonga-vaw-report-final-2012.pdf.

26. MHMS UNFPA. Kiribati Sexual and Reproductive Health Rights Needs Assessment. Suva Ministry for Health and Medical Services, United Nations Population Fund Pacific Sub Regional Office, Government of New Zealand; 2015. https://pacific.unfpa.org/sites/default/files/pub-pdf/5.Kirib atiSexualandReproductiveHealthRightsNeedsAssessmentReportLRv1.pdf.

27. WHO. Monitoring universal health coverage and health in the sustainable development goals: baseline report for the Western Pacific Region. Manila: World Health Organization Regional Office for the Western Pacific; 2017. http://iris.wpro.who.int/handle/10665.1/13963.

28. SPC UNFPA. Solomon Islands Family Health and Safety Study: A study on violence against women and children. Noumea: Secretariat of the Pacific Community, UNFPA; 2009 https://pacific.unfpa.org/sites/default/files/ pub-pdf/SolomonlslandsFamilyHealthandSafetyStudy.pdf.

29. MIA Marshall Islands UNFPA. Republic of the Marshall Islands National Study on Family Health and Safety. Majuro: Ministry of Internal Affairs, Republic of the Marshall Islands, UNFPA; 2014. https://asiapacific.unfpa. org/sites/default/files/pub-pdf/Marshall_Islands_national_family_health_ safety_survey_report_2014.pdf.

30. Palau MoH. Belau Family Health and Safety Study. Palau Ministry of Health, Australian Government's Department of Foreign Affairs and Trade, UNFPA; 2014. https://pacific.unfpa.org/sites/default/files/pub-pdf/Palau FHSSReportweb.pdf. 
31. Fiji Women's Crisis Centre: Somebody's Life, Everybody's Business! National Research on Women's Health and Life Experiences in Fiji (2010/2011): a survey exploring the prevalence, incidence and attitudes to intimate partner violence in Fiji. Suva: Fiji Women's Crisis Centre; 2013 https://pacificwomen.org/wp-content/uploads/2017/09/FWCC-NationalResearch-on-Womens-Health-Fiji.pdf.

32. UNFPA. Vanuatu Sexual and Reproductive Health Rights Needs Assessment. Suva: National Reproductive Maternal, Newborn, Child and Adolescent Health Committee, UNFPA, UNDP; 2015. https://pacific.unfpa. org/sites/default/files/pub-pdf/4.VanuatuSexualandReproductiveHealthR ightsNeedsAssessmentReportLRv1.pdf.

33. Pacific Islands Forum Secretariat. Pacific SDGs Progress Wheels. Pacific Islands Forum; 2018. https://www.forumsec.org/wp-content/uploads/ 2020/05/Pacific-SDG-Progress-Wheels.pdf.

34. Pacific Islands Forum Secretariat. first Quadrennial Pacific Sustainable Development. Suva, Fiji: Council of Regional Organisations in the Pacific, UN Agencies in the Pacific 2018. https://www.forumsec.org/wp-conte nt/uploads/2019/09/2018-1st-Quadrennial-Pacific-Sustainable-Devel opment-Report_final-as-of-July-4-2019.pdf.

35. WHO. Disability-inclusive health services toolkit: a resource for health facilities in the Western Pacific Region. Manila, Philippines: World Health Organization Regional Office for the Western Pacific; 2020. https://apps. who.int/iris/bitstream/handle/10665/336857/9789290618928-eng.pdf.

36. Sedgh G, Bearak J, Singh S, Bankole A, Popinchalk A, Ganatra B, Rossier C, Gerdts C, Tunçalp Ö, Johnson BR. Abortion incidence between 1990 and 2014: global, regional, and subregional levels and trends. Lancet. 2016;388:258.

37. Áhman E, Shah $\mathrm{H}$. New estimates and trends regarding unsafe abortion mortality. Int J Gynecol Obstet. 2011;115(2):121-6.

38. Ganatra B, Gerdts C, Rossier C, Johnson BR, Tunçalp Ö, Assifi A, Sedgh G, Singh S, Bankole A, Popinchalk A, et al. Global, regional, and subregional classification of abortions by safety, 2010-14: estimates from a Bayesian hierarchical model. Lancet. 2017;390(10110):2372-81.

39. ILGA. State Sponsored Homophobia A world survey of sexual orientation laws: criminalisation, protection and recognition. Geneva: International Lesbian, Gay, Bisexual, Trans and Intersex Association; 2016. https://ilga. org/downloads/02_ILGA_State_Sponsored_Homophobia_2016_ENG_ WEB_150516.pdf.

40. Park J, Nordstrom SK, Weber KM, Irwin T. Reproductive coercion: uncloaking an imbalance of social power. Am J Obstet Gynecol. 2016;214(1):74-8.

41. Panisi LR, Noguchi T, Kluckow H, Black K. A cross-sectional study of factors predicting antenatal patients' knowledge of modern methods of contraception in Honiara Solomon Islands. Pac J Reprod Health. 2019;1(9):500-5.

42. Guevara BF, Singh J, Fong J, Ekeroma A. Contraception of choice among postpartum women at the Colonial War Memorial Hospital, Fiji-a structured interview. Pac J Reprod Health. 2019;1(9):495-9.
43. Kennedy EC, Mackesy-Buckley S, Subramaniam S, Demmke A, Latu R, Robertson AS, Tiban K, Tokon A, Luchters S. The case for investing in family planning in the Pacific: costs and benefits of reducing unmet need for contraception in Vanuatu and the Solomon Islands. Reprod Health. 2013;10(1):30.

44. Silverman JG, Boyce SC, Dehingia N, Rao N, Chandurkar D, Nanda P, Hay K, Atmavilas Y, Saggurti N, Raj A. Reproductive coercion in Uttar Pradesh, India: prevalence and associations with partner violence and reproductive health. SSM Population Health. 2019;9:100484.

45. WHO. Regional framework for reproductive health in the Western Pacific Region. Manila: World Health Organization Regional office of the Western Pacific; 2013. https://iris.wpro.who.int/handle/10665.1/5279.

46. UN DESA: World Population Prospects 2019. New York: United Nations Department of Economic and Social Affairs Population Dynamics 2019. https://population.un.org/wpp/.

47. UNFPA: Population and development profiles pacific island countries. Suva: United Nations Population Fund Pacific Sub-Regional Office; 2014. https://pacific.unfpa.org/sites/default/files/pub-pdf/web_140414_ UNFPAPopulationandDevelopmentProfiles-PacificSub-RegionExtendedv 1LRV2_0.pdf.

48. UN DESA. Estimates and Projections of Family Planning Indicators 2020. New York: United Nations Department of Economic and Social Affairs Population Dynamics 2020. https://www.un.org/en/development/desa/ population/theme/family-planning/cp_model.asp.

49. UN DESA. Trends in Contraceptive Use Worldwide 2015. New York: United Nations Department of Economic and Social Affairs Population Dynamics 2015. https://www.un.org/en/development/desa/population/publicatio ns/pdf/family/trendsContraceptiveUse2015Report.pdf.

50. SPC. Pacific Sexual Health and Well-Being shared agenda: 2015-2019. Noumea: Secretariat of the Pacific Community; 2014. https://www.aidsd atahub.org/sites/default/files/resource/pacific-sexual-health-well-beingshared-agenda-2015-2019.pdf.

51. UNFPA. Measuring prevalence of violence against women in Asia-Pacific. New York: United Nations Population Fund; 2021. https://asiapacific. unfpa.org/en/knowvawdata.

52. Pacific Culture Areas. https://upload.wikimedia.org/wikipedia/commo ns/a/aa/Pacific_Culture_Areas.png.

\section{Publisher's Note}

Springer Nature remains neutral with regard to jurisdictional claims in published maps and institutional affiliations.

\footnotetext{
Ready to submit your research? Choose BMC and benefit from:

- fast, convenient online submission

- thorough peer review by experienced researchers in your field

- rapid publication on acceptance

- support for research data, including large and complex data types

- gold Open Access which fosters wider collaboration and increased citations

- maximum visibility for your research: over 100M website views per year
}

At BMC, research is always in progress.

Learn more biomedcentral.com/submissions 